\title{
Response surface methodology to optimize inulinase production by a newly isolated Penicillium amphipolaria strain by solid-state fermentation of Saccharum arundinaceum
}

Deblina Das

MIT, MAHE

Ramananda M Bhat

Department of Biotechnology, Manipal Institute of Technology (MIT), Manipal Academy of Higher Education (MAHE), Manipal, Karnataka

Raja Selvaraj ( $\sim$ raja.s@manipal.edu )

Manipal Institute of Technology https://orcid.org/0000-0002-3170-7899

\section{Research}

Keywords: Inulinase, Penicillium amphipolaria KAS 2555, Saccharum arundinaceum, Solid- state fermentation, Optimization, CCD, RSM

Posted Date: June 17th, 2020

DOI: https://doi.org/10.21203/rs.3.rs-33849/v1

License: (c) (i) This work is licensed under a Creative Commons Attribution 4.0 International License.

Read Full License 


\section{Abstract}

In the present investigation, a new fungal inulinase producer Penicillium amphipolaria KAS 2555 has been isolated from the soil of dead mangroves litter area, followed by the inulinase production and optimization by solid-state fermentation using a low-cost substrate - hardy sugarcane (Saccharum arundinaceum). While screening, only Penicillium amphipolaria KAS 2555 showed the hydrolysis zone on the plate containing inulin media. The exoinulolytic nature of inulinase and its form of action was confirmed by thin-layer chromatography (TLC). After $96 \mathrm{~h}$ of the fermentation period, an activity of 2.45 $\mathrm{U} / \mathrm{gds}$ was obtained. The I/S ratio of 0.59 proved that the enzyme is inulolytic in nature. Media optimization was performed to obtain a regression model using Central Composite Design (CCD). For optimization, five significant media components viz., inulin, $\left(\mathrm{NH}_{4}\right)_{2} \mathrm{SO}_{4}, \mathrm{~K}_{2} \mathrm{HPO}_{4}, \mathrm{KH}_{2} \mathrm{PO}_{4}$ and, $\mathrm{NaCl}$ were used. A 3.10-fold increase in activity of inulinase $(7.59 \mathrm{U} / \mathrm{gds})$ was obtained under the optimal settings of (g/gds) inulin- 0.1, $\left(\mathrm{NH}_{4}\right)_{2} \mathrm{SO}_{4^{-}} 0.002, \mathrm{~K}_{2} \mathrm{HPO}_{4}-0.1, \mathrm{KH}_{2} \mathrm{PO}_{4}-0.02$ and $\mathrm{NaCl}-0.02$.

\section{Introduction}

A variety of hydrolysing enzymes of industrial significance from various sources of microbes have been identified. Inulinases belong to one of these significant class of enzymes that acts on $\beta, 2-1$ linkages of inulin to yield different industrial products [1]. The $\beta, 2-1$ inulin linkages are affected by inulinases differently. They are therefore categorized as: exoinulinase and endoinulinase according to their pattern of action on inulin. Exoinulinase breaks inulin sequentially, while endoinulinase breaks the polymer internal links randomly to create varying chain length fructooligosaccharides [2].

The two main uses of inulinases are the processing of high fructose syrup and fructooligosaccharides [3]. Other inulinase applications are production of bioethanol [4], lactic acid [5], single-cell oil [6], and citric acid [7].

Being a low calorie sweetener, fructose is beneficial over traditional sucrose and fructooligosaccharides are effective prebiotics [8]. Usually, production of fructose from starch involves the use of three enzymes namely, a-amylase, amyloglucosidase and glucose isomerase which leads to only $45 \%$ yield. In contrast to this, inulinases are used in a single enzymatic inulin hydrolysis step which yields $95 \%$ of fructose [9].

Inulinase producing microbes have been widely isolated from sources like marine soil [10], rotten wood [11], inulin rich plants [12], etc. Mangrove soil is also proved to be an efficient source of inulinase producing fungi [13]. A mangrove habitat consists of two parts, production-based where living mangrove trees are found and dead-based where dead mangroves are found. Dead mangroves litter is made up of leaves, barks, seeds, branch, wood, etc. A wide range of microbes inhabits the different parts of the deadbased mangrove environment like soil, leaf, wood, algae, and sand. In the present study, topsoil from the rotten wood of mangrove trees has been used for the isolation of inulinase producing microbes [14]. Mangrove soil is a rich source of microbes that produces enzymes like chitinase, cellulase, protease, and amylase [15]. To date, there is no report on the production of inulinase or any other enzymes from 
Penicillium amphipolaria species. This is the first report on the solid state production of inulinase enzyme using this new fungal species isolated from the mangrove soil in the dead mangroves area.

Microbial sources of inulinases are bacteria, yeast and filamentous fungi. Nevertheless, there has been a considerable increase in fungal sources because of thermal and $\mathrm{pH}$ stability and growth on low cost substrates to produce important industrial products. Some active fungal inulinase producers are Aspergillus sp., Rhizopus sp., Penicillium sp., etc [16]. In the present study a new fungal species "Penicillium amphipolaria" has been isolated. Till date there is no report on the application of this fungus in any field of research.

In general, inulinase is produced by submerged fermentation, nonetheless, nowadays, solid-state fermentation (SSF) is gaining a lot of attention because of the low cost process. Several cheap substrates such as sugarcane bagasse, peels of onion, pressmud, wheat bran and rice bran have been used for the production of inulinase enzyme [17]. Very recently, our research group have documented the use of a cost-effective solid substrate - "Saccharum arundinaceum", usually called as hardy sugarcane, for the inulinase production by employing Aspergillus flavus var. flavus strain ATCC 16883 [13].

In the process of fermentation, media optimization is necessary to achieve optimal growth of microbes and enhance the synthesis of metabolites. The relevant statistical method of optimization i.e., response surface methodology (RSM) uses analysis of variance (ANOVA) and multiple regression analysis to analyse the optimum model [18]. RSM determines the optimum process conditions using Central composite design (CCD) and Box-Behnken design (BBD) [19]. Therefore, this method was used to optimize the media components of inulinase production by SSF from the rotten wood mangrove soil isolated fungus, $P$. amphipolaria. This is the first report on the production of inulinase from $P$. amphipolaria using dead-based mangrove soil as the chief source of fungal isolation.

\section{Materials And Methods}

\subsection{Isolation and screening of inulin- degrading fungal strains}

The method of isolation was performed using the surface soil of the rotten wood of the mangrove detritus situated in the estuary of Halady river, on the Herikudru island, Kundapura Taluk $\left(13^{\circ} 38^{\prime} 28^{\prime \prime} \mathrm{N}\right.$, $\left.74^{\circ} 42^{\prime} 01^{\prime} \mathrm{E}\right)$, India. Here, the mangrove area is mostly comprised of mangrove trees that have died due to urbanization and deforestation. The soil collection was done in July 2017. Firstly, a serial dilution of the soil sample was carried out followed by plating $0.1 \mathrm{ml}$ of the sample on the Czapex Dox Agar medium (CDA). CDA medium consists of (g/l): sucrose - 30, $\mathrm{K}_{2} \mathrm{HPO}_{4}-1, \mathrm{NaNO}_{3}-2, \mathrm{KCl}-0.50, \mathrm{MgSO}_{4}-0.50$, $\mathrm{FeSO}_{4}-0.01$ and agar -15 . It is used for the isolation of fungal species. The $\mathrm{pH}$ of the media was kept at 7.4 and autoclaved for $45 \mathrm{~min}$ at $121^{\circ} \mathrm{C}$ and $15-20 \mathrm{psi}$. The plates were incubated for $3-4$ days at $30^{\circ} \mathrm{C}$ to get diverse colonies of fungal species [13]. In the process of primary screening, individual colonies from different fungal colonies were selected and plated aseptically on inulin media. The inulin media consists of $(\mathrm{g} / \mathrm{l})$ : inulin - 6.00, $\mathrm{Na}_{2} \mathrm{HPO}_{4}-33.9, \mathrm{NH}_{4} \mathrm{Cl}-5, \mathrm{NaCl}-2.50, \mathrm{KH}_{2} \mathrm{PO}_{4}-15$, and agar -15 . The plates were 
incubated for three days at $30^{\circ} \mathrm{C}$. The pH of the media was kept at 6.7 [21]. Lugol's plate assay was performed to screen the microorganisms producing extracellular inulinases [22].

\subsection{Identification of the fungal strain}

The fungal strain which gave the highest activity was recognized using 18s rRNA gene sequencing

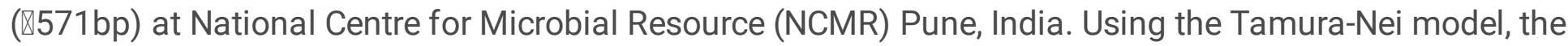
evolutionary history was inferred by using the Maximum Likelihood method. The tree was constructed using 1000 bootstrap. The bootstrap support is 95 for the parent node. Tree construction method was selected based on the best model fitting option in MEGA6 [41].

\subsection{Inoculum preparation}

The fungal spores were totally removed from the agar plates using $0.05 \%$ of sodium chloride solution. A haemocytometer (Improved Neubauer, Rohem, India) was used to count the number of cells. For SSF, $2 \times 10^{6}$ spores/ $\mathrm{mL}$ of spore suspension was used [23].

\subsection{Pretreatment of solid substrate}

Stems of S. arundinaceum collected from Chitpady colony, Udupi, India were cleaned properly couple of times in running water. Small cubes of the stems were prepared and sun-dried for a couple of days to remove moisture. Subsequently, fine powder was made by grinding the dried cubes in a mixer grinder and passed through a $1.18 \mathrm{~mm}$ sieve. After sieving, the particles with larger sizes were removed and the fine powder was used in SSF as a solid substrate.

\subsection{Solid-State Fermentation}

SSF was carried out by mixing $2 \mathrm{~g}$ of $S$. arundinaceum powder and $5 \mathrm{ml}$ of inulin media in $250 \mathrm{ml}$ conical flasks. Moisture on a dry basis was maintained at $77.8 \%$. All the flasks were tightly covered with hydrophobic cotton and autoclaved. The flasks were allowed to cool followed by the addition of $2 \mathrm{ml}$ of the spore suspension prepared earlier. Proper mixing of the solid substrate, fermentation media and the spore suspension was done to ensure the availability of nutrients uniformly. The flasks were incubated at $30^{\circ} \mathrm{C}$ for five days [42]. During the process of preliminary screening, it was found that the maximum production of inulinase occurred at $96^{\text {th }} \mathrm{h}$. All the subsequent experiments were thus carried out for $96 \mathrm{~h}$.

\subsection{Extraction of Inulinase enzyme}

For the extraction of enzyme after the completion of fermentation, the fermented contents were mixed with $30 \mathrm{ml}$ of sodium acetate buffer $(0.1 \mathrm{molar})$ having a pH of 4.75 . The flasks were then kept for $1 \mathrm{~h}$ on a rotary shaker (180rpm) to extract the enzyme. Subsequently, a clean muslin cloth was used to filter out the enzyme extract followed by centrifugation at 844 G-force $(10,000 \mathrm{rpm}$ in rotor 9 , Tabletop Superspin Centrifuge $-V / F_{M}$, Plasto Crafts., Mumbai) at $4{ }^{\circ} \mathrm{C}$ for $10 \mathrm{~min}$. The determination of reducing sugars was done by the dinitrosalicylic acid (DNS) method using the cell-free supernatant [25]. 


\subsection{Inulinase assay}

For the assay of inulinase enzyme, $2 \mathrm{~g}$ inulin was added to $10 \mathrm{ml}$ of $0.1 \mathrm{M}$ sodium acetate buffer to make a substrate solution. Then the reaction mixture which consisted of $0.9 \mathrm{ml}$ of substrate solution and $0.1 \mathrm{ml}$ of the cell-free supernatant was incubated for $10 \mathrm{~min}$, followed by the addition of $1 \mathrm{ml}$ of DNS reagent. The mixture was heated for $10 \mathrm{~min}$ in a water bath. For the blank, the enzyme was deactivated by preheating the reaction mixture. The quantity of enzyme which produces $1 \mu \mathrm{mol}$ of fructose per min is defined as one unit of inulinase activity.

Similar to inulinase assay, the invertase assay was determined using sucrose in the reaction mixture and the activity of invertase was determined with respect to the sucrose activity [21].

\subsection{Inulinase to Sucrose activity (I/S ratio)}

Usually, the inulinase activity is characterized from the activity of invertase using the I/S ratio. An I/S ratio higher than $10^{-2}$ proves to have a high production of inulinase whereas an $\mathrm{I} / \mathrm{S}$ ratio lower than $10^{-4}$ proves to have a high production of invertase enzyme in the culture media [2].

\subsection{Optimization of Inulinase Production}

Proper understanding and former knowledge of bioprocess are necessary to obtain a model with accuracy. The data obtained from the experiments were studied using "Minitab 16.2.2.0", a design software. Using Central composite design, a quadratic model was obtained. A fractional CCD 2(5-1) was used here and the significance level was kept at 95\%. CCD consists of factorial trials and star points which assist the defining of quadratic effects. The centre points assess the pure variance with inulinase production as the output variable [26]. The optimization of the five significant media constituents which increased the inulinase production was done using RSM. A set of thirty-two experiments were performed by studying the five components at 5 different levels, keeping zero as the central coded value. The experimental results of all the 32 experiments - the inulinase activity $(Y)$ were recorded and submitted to ANOVA to carry out the analysis of data using multiple regression [27]. Lastly, an empirical model showing the relationship between the independent components and the measured response was achieved.

\subsection{Analysis of end products}

The pattern in which inulinase enzyme works on inulin was figured out by thin-layer chromatography (TLC) analysis. To perform the reaction of hydrolysis, $1.0 \mathrm{ml}$ of the cell-free supernatant was mixed with $0.01 \mathrm{~g}$ of inulin. The reaction mixture was incubated at $56^{\circ} \mathrm{C}$ for six $\mathrm{h}$. Then, the reaction was stopped by boiling the reaction mixture for $10 \mathrm{~min}$. Along with the sample test $(T)$, four standards namely, deactivated inulinase (I), fructose $(F)$, glucose $(G)$, sucrose $(S)$, were spotted on the TLC plates. It was then air-dried and dipped in a developer solution composed of butanol:ethanol:water (50:30:20). The plate was again air-dried and sprayed with diphenylamine reagent (1\% diphenylamine, $10 \%$ phosphoric acid and $1 \%$ 
aniline). This reagent develops colors on reaction with sugars. Finally, the plate was kept in a hot air oven for $10 \mathrm{~min}$ at $120^{\circ} \mathrm{C}$ for drying [21].

\subsection{Seliwanoff's test}

To distinguish between aldoses and ketoses, Seliwanoff's color test is carried out. Ketose sugar can be differentiated from aldose sugar by the formation of a burgundy or cherry red color with resorcinol on condensation, whereas aldose sugar doesn't give any color [28]. Heating for a long time is avoided as aldose sugars will also give a red color [29]. To perform this test, three controls namely fructose, glucose and deactivated inulinase with inulin was used and a test sample containing the supernatant along with inulinase and inulin was used. $0.5 \mathrm{ml}$ of the test sample was mixed with $1 \mathrm{ml}$ of Seliwanoff's reagent and heated for $2 \mathrm{~min}$. To $1 \mathrm{ml}$ of Seliwanoff's reagent, $1 \mathrm{ml}$ each of the following, namely, standard fructose, standard glucose, and a pre-heated mixture of deactivated inulinase and inulin were also mixed and heated for $2 \mathrm{~min}$.

\subsection{Osazone formation test}

Osazone test is performed to determine and identify the sugars qualitatively. It is a simple test in which sugars form distinctive crystals of osazone on reaction with phenylhydrazine. Distinctive broom and needle- shaped osazones are formed by monosachharides like glucose and fructose. The following test was carried out using the optimized cell-free liquid of inulinase and inulin mixture along with the fructose control. $2 \mathrm{ml}$ of the control fructose and $2 \mathrm{ml}$ of the supernatant were mixed with phenylhydrazine hydrochloride solution followed by heating for $30 \mathrm{~min}$ in a water bath [30]. After cooling down of the solutions, the distinctive images of the osazone crystals were visualized by a light microscope (Euromex iscope, Holland) at 40x magnification.

\section{Results And Discussions}

\subsection{Microorganism}

The fungal isolate that has grown on the inulin media were chosen for Lugol's plate assay. The fungal strain which had formed a clear halo in the plate assay has been indicated as DD MSF 1 in Fig. 1a and Fig. 1b. Figure 1a shows that the isolate has moderately deep colonies, white mycelia, and floccose texture. Visagie et al., (2016) reported the same features for Penicillium amphipolaria KAS 2555. They isolated this species from the quarter main mountains of the dry valleys of Antarctica [31]. Till date, there is no work reported in any field on this fungal species. Figure 2 shows DD MSF 1 represented in the phylogenetic tree as sequenced by NCMR Pune, India. DD MSF 1 was found to have a $99 \%$ similarity with Penicillium amphipolaria strain KAS 2555. This study reports the isolation of this fungal species from detritus mangrove soil for the first time. In the GenBank under the (Accession number KT887872.1), the gene sequence of the ribosomal RNA of DD MSF 1 has been deposited. Among the fungal producers of inulinases, the Penicillium genus is one of the most common. According to the literature survey, species 
such as $P$. brevicompactum [11], P. rugulosum [32], P. citrinum [23], have been used for the production of inulinase enzyme.

\subsection{Fermentation and optimization of the significant nutrients}

After the completion of $96 \mathrm{~h}$ of fermentation, DD MSF 1 yielded a maximal activity of $2.45 \mathrm{U} / \mathrm{gds}$. The activity gradually decreased after $96 \mathrm{~h}$ with the increase in the incubation period possibly due to the carbon source exhaustion in the fermentation media, catabolic repression, or due to the secretion of proteolytic proteins causing the denaturation of proteins. The experimental time of fermentation is consistent with the reported values. A maximal inulinase activity of $3.48 \mathrm{U} / \mathrm{gds}$ was obtained from $A$. flavus ATCC 16883 [13], A. terreus gave a maximum activity of $5.680 \pm 0.183 \mathrm{U} / \mathrm{gds}$ [11], a maximal activity of $319 \mathrm{U} / \mathrm{ml}$ was obtained from A. niger ATCC 20611 in shake flask [33]. Penicillium amphipolaria KAS 2555 gave an I/S ratio of 0.59 , hence, proved the specificity of the enzyme inulinase. The result obtained in the present study had similarities with other microbial producers of inulinases as reported in the literature. An I/S ratio of 2.56 was obtained from A. flavus ATCC 16883 [13], a ratio of 3.38 was obtained from $P$. oxalicum BGPUP-4 [21], a ratio in the range of 0.53-0.66 was obtained from Penicillium $s p$. NFCC 2768 [34], a ratio of 0.57-2.49 was obtained from Rhizopus microspores 13alV [35].

During the preliminary process of traditional screening, five nutrient components viz., inulin, $\left(\mathrm{NH}_{4}\right)_{2} \mathrm{SO}_{4}$, $\mathrm{K}_{2} \mathrm{HPO}_{4}, \mathrm{KH}_{2} \mathrm{PO}_{4}$, and $\mathrm{NaCl}$ were screened out to be significant and their levels were determined for $\mathrm{CCD}$ as shown below in Table 1a. Thirty two experiments were performed according to the combinations given by the software. The number of runs were kept randomized. The process parameters were kept constant as follows: temperature $\left(30^{\circ} \mathrm{C}\right)$, moisture $(77.77 \%)$, inoculum size $\left(2 \mathrm{ml}\right.$ of $2 \times 10^{6}$ fungal spores), amount of solid substrate $(2 \mathrm{~g})$, fermentation media $(5 \mathrm{ml}), \mathrm{pH}(7)$.The results are compared with the published reports. Four significant nutrients namely $\mathrm{NH}_{4} \mathrm{NO}_{3}$, soya bean cake, $\mathrm{MnSO}_{4} \cdot 7 \mathrm{H}_{2} \mathrm{O}$, and $\mathrm{K}_{2} \mathrm{HPO}_{4}$ were screened by Dilipkumar et al., (2011) for the of inulinase production by Streptomyces sp. in SSF [24]. Three significant nutrients viz. FeSO ${ }_{4} .7 \mathrm{H}_{2} \mathrm{O}$, yeast extract, and $\mathrm{NH}_{4} \mathrm{NO}_{3}$ were screened by Dilipkumar et al., (2011) for inulinase optimization in SSF by Streptomyces $s p$ [36]. Five significant factors namely, inoculum size, moisture, the ratio of the quantity of wheat bran to rice husk, $\mathrm{pH}$ and temperature were screened by Sheng et al., (2009) for the optimization of inulinase enzyme using Cryptococcus aureus G7a in SSF [37].

Among the significant term, the optimum values were determined by CCD. In run 10, the highest activity of $7.38 \mathrm{U} / \mathrm{gds}$ and in run 22 , the lowest activity of $5.74 \mathrm{U} / \mathrm{gds}$ were obtained as presented in Table $1 \mathrm{~b}$. The data obtained from the experiments are reproducible significantly as there is a small difference between the central points. ANOVA was used for the design of the experiment to determine the model efficiency and fitness as shown in Table 2. F value of the model is shown as 10.24 which proves that it is significant. 
At a $95 \%$ level of confidence and a ( $p$-value $<0.05), X_{1}$ is significant among the linear model factors, $X_{2}^{2}$ and $X_{3}^{2}$ are significant among the square interactions and $X_{1} * X_{2}, X_{2} * X_{4}$ are significant among the two way interactions. The coefficient of determination $\left(R^{2}\right)$ for the activity of the inulinase enzyme was calculated as 0.9490 which is responsible for causing a $94.90 \%$ variation in the response.

Table 1

a- Levels of the independent variables chosen for Central Composite Design.

\begin{tabular}{|llllll|}
\hline Nutrient factors (g/gds) & \multicolumn{2}{l}{ Levels } & & & \\
\cline { 2 - 6 } & $\mathbf{( - 2})$ & $(-1)$ & $(\mathbf{0})$ & $(\mathbf{+})$ & $(\mathbf{+})$ \\
\hline Inulin & 0.0100 & 0.0325 & 0.0550 & 0.0775 & 0.1000 \\
$\mathrm{~K}_{2} \mathrm{HPO}_{4}$ & 0.0500 & 0.0625 & 0.0750 & 0.0875 & 0.1000 \\
$\left(\mathrm{NH}_{4}\right)_{2} \mathrm{SO}_{4}$ & 0.0020 & 0.0065 & 0.0110 & 0.0155 & 0.0200 \\
$\mathrm{KH}_{2} \mathrm{PO}_{4}$ & 0.0050 & 0.00875 & 0.01250 & 0.01625 & 0.0200 \\
$\mathrm{NaCl}$ & 0.0020 & 0.0065 & 0.0110 & 0.0155 & 0.0200 \\
\hline
\end{tabular}


Table 1

b-Central composite design matrix to determine the optimum values of the five nutrient factors for the production of inulinase.

\begin{tabular}{|c|c|c|c|c|c|c|c|}
\hline \multirow{3}{*}{$\begin{array}{l}\text { Runs } \\
\text { Run } \\
\text { Order }\end{array}$} & \multicolumn{5}{|c|}{ Nutrient factors with codes (g/gds) } & \multicolumn{2}{|c|}{ Inulinase activity (U/gds) } \\
\hline & Inulin & $\mathrm{K}_{2} \mathrm{HPO}_{4}$ & $\left(\mathrm{NH}_{4}\right)_{2} \mathrm{SO}_{4}$ & $\mathrm{KH}_{2} \mathrm{PO}_{4}$ & $\mathrm{NaCl}$ & Inulinase & Predicted \\
\hline & $\left(\mathrm{X}_{1}\right)$ & $\left(X_{2}\right)$ & $\left(X_{3}\right)$ & $\left(X_{4}\right)$ & $\left(\mathrm{X}_{5}\right)$ & & \\
\hline 1 & 0.055 & 0.075 & 0.011 & 0.02 & 0.011 & 6.90 & 6.81 \\
\hline 2 & 0.0775 & 0.0625 & 0.0065 & 0.00875 & 0.0065 & 5.92 & 5.74 \\
\hline 3 & 0.055 & 0.075 & 0.002 & 0.0125 & 0.011 & 6.70 & 6.88 \\
\hline 4 & 0.055 & 0.075 & 0.02 & 0.0125 & 0.011 & 7.16 & 6.99 \\
\hline 5 & 0.055 & 0.075 & 0.011 & 0.0125 & 0.011 & 6.49 & 6.53 \\
\hline 6 & 0.0775 & 0.0625 & 0.0155 & 0.01625 & 0.0065 & 6.17 & 6.12 \\
\hline 7 & 0.055 & 0.075 & 0.011 & 0.0125 & 0.011 & 6.51 & 6.53 \\
\hline 8 & 0.055 & 0.075 & 0.011 & 0.005 & 0.011 & 6.59 & 6.69 \\
\hline 9 & 0.055 & 0.075 & 0.011 & 0.0125 & 0.002 & 6.67 & 6.82 \\
\hline 10 & 0.0325 & 0.0625 & 0.0065 & 0.01625 & 0.0065 & 7.38 & 7.30 \\
\hline 11 & 0.0325 & 0.0875 & 0.0065 & 0.01625 & 0.0155 & 5.78 & 5.85 \\
\hline 12 & 0.0325 & 0.0875 & 0.0065 & 0.00875 & 0.0065 & 6.58 & 6.53 \\
\hline 13 & 0.0325 & 0.0625 & 0.0155 & 0.00875 & 0.0065 & 7.01 & 6.97 \\
\hline 14 & 0.055 & 0.1 & 0.011 & 0.0125 & 0.011 & 6.25 & 6.10 \\
\hline 15 & 0.055 & 0.075 & 0.011 & 0.0125 & 0.011 & 6.50 & 6.53 \\
\hline 16 & 0.055 & 0.075 & 0.011 & 0.0125 & 0.011 & 6.56 & 6.53 \\
\hline 17 & 0.0325 & 0.0875 & 0.0155 & 0.01625 & 0.0065 & 6.31 & 6.40 \\
\hline 18 & 0.0325 & 0.0625 & 0.0155 & 0.01625 & 0.0155 & 7.24 & 7.32 \\
\hline 19 & 0.0775 & 0.0875 & 0.0065 & 0.00875 & 0.0155 & 7.05 & 7.02 \\
\hline 20 & 0.0775 & 0.0875 & 0.0155 & 0.00875 & 0.0065 & 7.20 & 7.19 \\
\hline 21 & 0.0325 & 0.0875 & 0.0155 & 0.00875 & 0.0155 & 6.15 & 6.26 \\
\hline 22 & 0.0775 & 0.0625 & 0.0155 & 0.00875 & 0.0155 & 5.74 & 5.72 \\
\hline 23 & 0.0325 & 0.0625 & 0.0065 & 0.00875 & 0.0155 & 7.01 & 6.96 \\
\hline 24 & 0.055 & 0.075 & 0.011 & 0.0125 & 0.02 & 6.88 & 6.74 \\
\hline
\end{tabular}




\begin{tabular}{|llllllll|}
\hline Runs & \multicolumn{2}{l}{ Nutrient factors with codes (g/gds) } & \multicolumn{3}{l|}{ Inulinase activity (U/gds) } \\
\hline 25 & 0.055 & 0.075 & 0.011 & 0.0125 & 0.011 & 6.57 & 6.53 \\
\hline 26 & 0.055 & 0.075 & 0.011 & 0.0125 & 0.011 & 6.60 & 6.53 \\
\hline 27 & 0.0775 & 0.0875 & 0.0065 & 0.01625 & 0.0065 & 6.60 & 6.55 \\
\hline 28 & 0.055 & 0.05 & 0.011 & 0.0125 & 0.011 & 5.91 & 6.07 \\
\hline 29 & 0.0775 & 0.0625 & 0.0065 & 0.01625 & 0.0155 & 6.53 & 6.47 \\
\hline 30 & 0.1 & 0.075 & 0.011 & 0.0125 & 0.011 & 5.96 & 6.07 \\
\hline 31 & 0.0775 & 0.0875 & 0.0155 & 0.01625 & 0.0155 & 6.79 & 6.90 \\
\hline 32 & 0.01 & 0.075 & 0.011 & 0.0125 & 0.011 & 6.64 & 6.54 \\
\hline
\end{tabular}


Table 2

Analysis of variance for the quadratic regression model obtained from central composite design for optimal inulinase activity

\begin{tabular}{|c|c|c|c|c|}
\hline Source & Effect & Coefficient & F-value & $\mathrm{P}$-value \\
\hline Model & & & 10.24 & 0.000 \\
\hline Linear & & & 2.85 & 0.069 \\
\hline \multicolumn{5}{|l|}{ Constant } \\
\hline$\left(X_{1}\right)$ Inulin & -0.2350 & -0.1175 & 12.29 & 0.005 \\
\hline$\left(\mathrm{X}_{2}\right) \mathrm{K}_{2} \mathrm{HPO}_{4}$ & 0.0117 & 0.0058 & 0.03 & 0.865 \\
\hline$\left(\mathrm{X}_{3}\right)\left(\mathrm{NH}_{4}\right)_{2} \mathrm{SO}_{4}$ & 0.0567 & 0.0283 & 0.71 & 0.416 \\
\hline$\left(\mathrm{X}_{4}\right) \mathrm{KH}_{2} \mathrm{PO}_{4}$ & 0.0633 & 0.0317 & 0.89 & 0.365 \\
\hline$\left(\mathrm{X}_{5}\right) \mathrm{NaCl}$ & -0.0383 & -0.0192 & 0.33 & 0.579 \\
\hline \multicolumn{5}{|l|}{ Square } \\
\hline$x_{1}^{2}$ & -0.1125 & -0.0563 & 3.44 & 0.091 \\
\hline$x_{2}^{2}$ & -0.2225 & -0.1112 & 13.46 & 0.004 \\
\hline$x_{3}^{2}$ & 0.2025 & 0.1013 & 11.15 & 0.007 \\
\hline$x_{4}^{2}$ & 0.1100 & 0.0550 & 3.29 & 0.097 \\
\hline$x_{5}^{2}$ & 0.1250 & 0.0625 & 4.25 & 0.064 \\
\hline \multicolumn{5}{|c|}{ 2-Way Interaction } \\
\hline$X_{1} * X_{2}$ & 0.8875 & 0.4437 & 116.84 & 0.000 \\
\hline$x_{1} * x_{3}$ & -0.0200 & -0.0100 & 0.06 & 0.812 \\
\hline$X_{1} * X_{4}$ & 0.0275 & 0.0137 & 0.11 & 0.744 \\
\hline$X_{1} * X_{5}$ & 0.1650 & 0.0825 & 4.04 & 0.070 \\
\hline$x_{2} * x_{3}$ & 0.1400 & 0.0700 & 2.91 & 0.116 \\
\hline$X_{2} * X_{4}$ & -0.3925 & -0.1962 & 22.85 & 0.001 \\
\hline$x_{2} * X_{5}$ & -0.1200 & -0.0600 & 2.14 & 0.172 \\
\hline$x_{3}{ }^{*} X_{4}$ & 0.0850 & 0.0425 & 1.07 & 0.323 \\
\hline
\end{tabular}




\begin{tabular}{|lllll|}
\hline Source & Effect & Coefficient & F-value & P-value \\
\hline$X_{3}{ }^{*} X_{5}$ & -0.0825 & -0.0412 & 1.01 & 0.337 \\
\hline$X_{4}{ }^{*} X_{5}$ & 0.0800 & 0.0400 & 0.95 & 0.351 \\
\hline
\end{tabular}

\section{Regression model equation with uncoded values}

Inulinase activity $(U / g d s)=7.61-121.2 X_{1}+70.9 X_{2}-200.7 X_{3}+161.9 X_{4}-44.2 X_{5}-111.1 X_{1}^{2}-712 X_{2}^{2}+$ $5000 X_{3}^{2}+3911 X_{4}^{2}+3086 X_{5}^{2}+1578 X_{1} * X_{2}-99 X_{1} * X_{3}+163 X_{1} * X+815 X_{1} * X_{5}+1244 X_{2} * X_{3}-4187$ $X_{2} \star X_{4}-1067 X_{2} \star X_{5}+2519 X_{3} \star X_{4}-2037 X_{3} \star X_{5}+2370 X_{4} \star X_{5}$

The main source of energy and skeletal support to the cells of microbes are provided by the carbon sources. Thus, inulin came out to be the most significant among the other variables. Penicillium amphipolaria KAS 2555 produces inulinase using inulin as the only carbon substrate which induces the production process. Yet a large amount of inulin leads to a decrease in the inulinase activity as shown in Fig. 3 due to catabolite repression. $\mathrm{K}_{2} \mathrm{HPO}_{4}$ and $\mathrm{KH}_{2} \mathrm{PO}_{4}$ act as a buffer and helps in basic cell growth. The inulinase activity decreases with an increase in $\mathrm{KH}_{2} \mathrm{PO}_{4}$ as presented in Fig. 4. This inhibitory effect on the inulinase activity could be the result of phosphate ions released in excess. Ammonium sulphate is an important source which provides nitrogen in the growth of $P$. amphipolaria KAS 2555 . However, the inulinase activity decreases in higher concentration possibly due to excess release of ammonium ions [43]. Another important factor, $\mathrm{NaCl}$ helps to maintain the osmotic balance in the growth media. The inulinase activity decreases as the concentration of $\mathrm{NaCl}$ increases possibly due to salinity stress which slows down the water transportation rate in and outside the fungal cells [44].

Singh et al., (2018) reported $\mathrm{KH}_{2} \mathrm{PO}_{4}$ as one of the significant factors in the inulinase production from Mucor circinelloides BGPUP-9 [38]. Dilipkumar et al., (2011) reported $\mathrm{K}_{2} \mathrm{HPO}_{4}$ as one of the significant factors in the production of inulinase from Streptomyces sp. MTCC-3119 [24]. Xiong et al., (2007) reported inulin as one of the significant factors in the production of inulinase from Kluyveromyces $\mathrm{S} 120$ [39]. Abd El Aty et al., (2014) reported $\mathrm{KH}_{2} \mathrm{PO}_{4}$ as one of the significant factors in the production of inulinase from Aspergillus terreus [11]. As the concentration of the five media components is increased above the peak level, the activity of the inulinase enzyme is suppressed although there is continued slow growth of the cells. On the other hand, if the concentration of the media components decreases, the growth of the microbes and the activity of the inulinase enzyme will rapidly decrease [13].

\subsection{Regression model validation}

The model validation was performed by the respective optimized values of the significant terms for the production of inulinase: Inulin-0.1, $\mathrm{K}_{2} \mathrm{HPO}_{4^{-}} 0.1,\left(\mathrm{NH}_{4}\right)_{2} \mathrm{SO}_{4^{-}} 0.002, \mathrm{KH}_{2} \mathrm{PO}_{4^{-}} 0.02$ and $\mathrm{NaCl}-0.02$ (g/gds). The experimental inulinase activity using these values was found out to be $7.59 \mathrm{U} / \mathrm{gds}$ which was in agreement with the predicted inulinase activity of $7.53 \mathrm{U} / \mathrm{gds}$. The inulinase activity obtained in the 
current study is 3.1 times higher than the un-optimized value. A comparison of the inulinase activity with the existing literature for few fungal species is given in Table 3.

Table 3

Comparison of inulinase activity with few fungal species

\begin{tabular}{|llll|}
\hline Microorganism & Substrate & $\begin{array}{l}\text { Inulinase yield } \\
\text { (U/gds) }\end{array}$ & References \\
\hline Aspergillus versicolor & Orange rinds & 1.917 & {$[11]$} \\
\hline Aspergillus terreus & Artichoke leaves & 4.433 & {$[13]$} \\
\hline Aspergillus flavus ATCC 16883 & $\begin{array}{l}\text { Saccharum } \\
\text { arundinaceum }\end{array}$ & 8.57 & $\begin{array}{l}\text { Present } \\
\text { Work }\end{array}$ \\
$\begin{array}{l}\text { Penicillium amphipolaria KAS } \\
2555\end{array}$ & $\begin{array}{l}\text { Saccharum } \\
\text { arundinaceum }\end{array}$ & 2.45 (un-optimized) \\
$\begin{array}{l}\text { Penicillium amphipolaria KAS } \\
2555\end{array}$ & $\begin{array}{l}\text { Saccharum } \\
\text { arundinaceum }\end{array}$ & 7.59 (optimized) & $\begin{array}{l}\text { Present } \\
\text { Work }\end{array}$ \\
\hline
\end{tabular}

There is no literature to date, on the production of inulinase from Penicillium amphipolaria KAS 2555 both by submerged and solid-state fermentation. For the first time, using hardy sugarcane, this new fungal strain has shown the viability of producing the enzyme inulinase on a laboratory scale by SSF. Optimized inulinase yield (7.59U/gds) as obtained from the present study is comparable with the optimized inulinase yield (8.57U/gds) from our previous study. Only a yield difference of $0.11 \mathrm{U} / \mathrm{gds}$ is observed between them. This study proved the efficiency of the mangrove soil containing dead mangroves litter also has good inulinases producing microbes like the soil from living mangroves litter.

\subsection{Analysis of hydrolysis products}

The TLC plate showed spots of fructose standard (F), glucose standard (G), sucrose standard (S) and the test sample $(T)$ containing the products of hydrolysis. No spot was observed for the control (I) containing inactivated inulinase and inulin. A single-colored spot obtained for the test sample proved that only fructose and a minute quantity of glucose is present in the hydrosylate. No fructooligosachharides were present which concludes the exoinulotytic nature of Penicillium amphipolaria KAS 2555. Some of the reported fungal microbes like A. fumigatus [40], A. flavus ATCC 16883[13], P. oxalicum BGPUP-4 [21], etc are exoinulolytic in nature.

\subsection{Seliwanoff's test}

In the Seliwanoff's test, as depicted in Fig. 6, the test solution (4) and the fructose control (1) quickly formed a red color while heating, whereas there was no change in color in the test sample (3) containing the heat-inactivated inulinase enzyme and the glucose control (2). This color visibility proves that the fermented culture contains ketose sugar. 


\subsection{Osazone formation test}

Phenylhydrazine contains a free carbonyl moiety which reacts with the sugars to form broom and needleshaped crystals. Similar shaped osazones were visualized under (40x) magnification in a light microscope for both the standard fructose and the test broth. Similar shaped osazones were also reported by Hassid and McCready (1942)[30], Kamble et al., (2019) [12], Das et al., (2019)[13].

\section{Conclusion}

In the present study, a potential new inulinase producing fungus Penicillium amphipolaria KAS 2555 was isolated from the detritus mangrove environment. According to our previous study using Aspergillus flavus var. flavus ATCC16883, living mangrove environment proved to be a rich source of organisms capable of exhibiting inulinase activity. In the present study, dead mangrove environment also proved to be a rich source of microbes producing inulinase. This fungal species gave a good yield of extracellular inulinase in SSF using hardy sugarcane. An increase of 3.10 fold was obtained in SSF using the statistical design of experiment. The study by CCD helped in determining the significance of the nutrients present in the media. Among the five factors, inulin was found to be significant. As per the cited literature, no work has been done on Penicillium amphipolaria KAS 2555 for the production of inulinase or any other enzymes. Thus, the newly isolated fungal species, Penicillium amphipolaria KAS 2555 proved to be an efficient producer of inulinase enzyme, leading to the production of fructose in a single step. Further, scale-up studies can be done to enhance the enzyme production.

\section{Abbreviations}

RSM

Response Surface Methodology

CCD

Central Composite Design

ANOVA

Analysis of Variance

SSF

Solid Substrate Fermentation

CDA

Czapex Dox Agar medium

DNS

dinitrosalicylic acid

TLC

Thin Layer Chromatography

\section{Declarations}




\subsection{Funding \\ Dr. T.M.A. Pai Ph.D. scholarship}

\subsection{Acknowledgements:}

The financial support received from Dr. T.M.A. Pai Ph.D. scholarship programme provided by Manipal Academy of Higher Education (MAHE) is gratefully acknowledged.

\subsection{Author contributions:}

The original idea was suggested by MRB and RS. The experimental work was carried out by DD with guidance from MRB and RS. DD drafted the article. All the authors involved in the critical revision of the article for important intellectual content. All the authors read and approved the final manuscript.

\subsection{Competing interests:}

The authors have declared no competing interests

\subsection{Availability of data and materials}

The datasets used and/or analyzed during the current study are available from the corresponding author on reasonable request.

\subsection{Ethics approval and consent to participate}

Not applicable.

\subsection{Consent for publication}

Not applicable.

\section{References}


1. Pandey A, Soccol CR, Selvakumar P, Soccol VT, Krieger N, Fontana JD (1999) Recent Developments in Microbial Inulinases: Its Production, Properties, and Industrial Applications.

ApplBiochemBiotechnol 81:35-52

2. Neagu C, Bahrim G (2011) Inulinases-a versatile tool for biotechnology. InnovRomFood Biotechnol 9:1-11

3. Singh P, Gill PK (2006) Production of Inulinases: Recent Advances. Food Technol Biotechnol 44:151162

4. Gencheva P, Dobrev G, Delchev N, Hristov J, Ivanova V (2012) Jerusalem Artichoke and Pea Hulls Based Substrates as Raw Material for Ethanol Production by Saccharomyces cerevisiae. IRECHE 4:84-90

5. Petrova P, Velikova P, Popova L, Petrov K (2015) Direct conversion of chicory flour into L (+) -lactic acid by the highly effective inulinase producer Lactobacillus paracasei DSM 23505. Bioresour Technol 186:329-333

6. Zhao CH, Zhang T, Li M, Chi ZM (2010) Single cell oil production from hydrolysates of inulin and extract of tubers of Jerusalem artichoke by Rhodotorula mucilaginosa TJY15a. Process Biochem 45:1121-1126

7. Liu XY, Chi Z, Liu GL, Wang F, Madzak C, Chi ZM (2010) Inulin hydrolysis and citric acid production from inulin using the surface-engineered Yarrowia lipolytica displaying inulinases. Metab Eng 12:469-476

8. Kango N, Jain SC (2011) Production and Properties of Microbial Inulinases: Recent Advances. Food Biotechnol 25:165-212

9. Singh RS, Chauhan K (2018) Production, purification, characterization and applications of fungal inulinases. Curr Biotechnol 7:242-260

10. Gao L, Chi Z, Sheng J, Wang L, Li J, Gong F (2007) Inulinase-producing Marine Yeasts: Evaluation of their Diversity and Inulin Hydrolysis by Their Crude Enzymes. Microb Ecol 54:722-729

11. Abd El AA, Aty HR, Wehaidy FA, Mostafa (2014) Optimization of Inulinase Production from Low Cost Substrates Using Plackett-Burman and Taguchi Methods. Carbohydr Polym 102:261-268

12. Kamble PP, Suryawanshi SS, Jadhav JP, Attar YC (2019) Enhanced inulinase production by Fusarium solani JALPK from invasive weed using response surface methodology. J Microbiol Methods 159:99-111

13. Das D, Bhat MR, Selvaraj R (2019) Optimization of inulinase production by a newly isolated strain Aspergillus flavus var. flavus by solid state fermentation of Saccharum arundinaceum, Biocatal. Agric Biotechnol 22:101363

14. Sarma VV, Hyde KD (2001) A review on frequently occurring fungi in mangroves. Fungal Divers 8:134

15. Kathiresan K, Saravanakumar K, Anburaj R, Gomathi V, Abirami G, Sahu SK, Anandhan S (2011) Microbial Enzyme Activity in Decomposing Leaves of Mangroves. Int J Adv Biotechnol Res 2:382389

Page $16 / 24$ 
16. Das D, Bhat MR, Selvaraj R (2019) Review of Inulinase Production Using Solid-State Fermentation. Ann Microbiol 69:201-209

17. Singh RS, Chauhan K, Kennedy JF (2017) A panorama of bacterial inulinases: Production, purification, characterization and industrial applications. Int J Biol Macromol 96:312-322

18. Speck F, Raja S, Ramesh V, Thivaharan V (2016) Modelling and optimization of homogenous photoFenton degradation of rhodamine $B$ by response surface methodology and artificial neural network. Int J Environ Res 10:543-554

19. Sridevi V, Mahanty CLVV, Adimadhyam SVN, Medicherla NR (2011) Statistical optimization of process variables by response surface methodology to enhance phenol degradation by Pseudomonas putida (NCIM 2102). Adv Biosci Biotechnol 2:175-181

20. Guttikonda STK, Vanitha S, Anuradha K (2017) Screening of inulinase producing bacteria from diverse sources. Bio Disc 8:695-701

21. Singh RS, Chauhan K (2017) Inulinase production from a new inulinase producer, Penicillium oxalicum BGPUP-4, Biocatal. Agric Biotechnol 9:1-10

22. Li AX, Guo LZ, Fu Q, Lu WD (2011) A simple and rapid plate assay for screening of inulin degrading microorganisms using Lugol's iodine solution, Afr. J Biotechnol 10:9518-9521

23. Lafuente-Castaneda C, Martinez G, Contreras-Esquivel JC, Rodriguez-Herrera R, Prado-Barragan A, Aguilar CN (2012) Inulinase production by Penicillium citrinum ESS in submerged and solid-state cultures. Am J Agric Biol Sci 7:129-134

24. Dilipkumar M, Rajasimman M, Rajamohan N (2011) Optimization of Inulinase Production from Garlic by Streptomyces Sp. in Solid State Fermentation Using Statistical Designs. Biotechnol Res Int 2011:1-7

25. Miller GL (1959) Use of dinitrosalicylic acid reagent for determination of reducing sugar. Anal Chem $31: 426-428$

26. Olawoye B, A Comprehensive Handout on Central Composite Design (CCD), (2016)

27. Raja S, Murty VR (2013) Optimization of aqueous two-phase systems for the recovery of soluble proteins from tannery wastewater using response surface methodology. J Eng 2013:1-10

28. Sánchez-viesca F, Gómez R (2018) Reactivities Involved in the Seliwanoff Reaction Reactivities Involved in the Seliwanoff Reaction. MC 6:1-5

29. Devmurari VV, Bhadaniya CP, Ambasana PA (2018) A Comparative Study on Phyto-Constitutional Profiling of Carica Papaya Leaves. J ApplicableChem 7:1011-1017

30. Hassid W, McCready R (1942) Identification of sugars by microscopic appearance of crystalline osazones. Ind Eng Chem Anal Ed 14:683-686

31. Visagie1 CM, Renaud JB, Burgess KMN, Malloch DW, Clark D, Ketch L, Urb M, Louis-Seize G 1, Assabgui R, Sumarah MW, Seifert KA (2016) Fifteen new species of Penicillium. Persoonia 36:247280 
32. Dilipkumar M, Rajasimman M, Rajamohan N (2014) Utilization of Copra Waste for the Solid State Fermentatative Production of Inulinase in Batch and Packed Bed Reactors. Carbohydr Polym 102:662-668

33. Dinarvand M, Rezaee M, Masomian M, Jazayeri SD, Zareian M, Abbasi S, Ariff AB, Effect of C/N Ratio and Media Optimization through Response Surface Methodology on Simultaneous Productions of Intra-and Extracellular Inulinase and Invertase from Aspergillus Niger ATCC 20611, Biomed Res. Int. 2013(2013) 1-13

34. Rawat HK, Jain SC, Kango N, Production and properties of inulinase from Penicillium sp. NFCC 2768 grown on inulin-rich vegetal infusions, BIOCATAL BIOTRANSFOR. 33(2015) 61-68

35. Flores-Gallegos AC, Contreras-Esquivel JC, Morlett-Chávez JA, Aguilar CN (2015) R. RodriguezHerrera, Comparative Study of Fungal Strains for Thermostable Inulinase Production. J Biosci Bioeng 119:421-426

36. Dilipkumar M, Rajasimman M, Rajamohan N (2011) Application of Statistical Design for the Production of Inulinase by Streptomyces Sp. Using Pressmud. Front Chem Sci Eng 5:463-470

37. Sheng J, Chi Z, Yan K, Wang X, Gong F, Li J (2009) Use of Response Surface Methodology for Optimizing Process Parameters for High Inulinase Production by the Marine Yeast Cryptococcus Aureus G7a in Solid-State Fermentation and Hydrolysis of Inulin. Bioprocess Biosyst Eng 32:333339

38. Singh RS, Chauhan K, Kaur R, Kaur R (2018) Inulinase production in shake-flask fermentations from Mucor circinelloides BGPUP-9. J Appl Biol Biotechnol 6:018-025

39. Xiong C, Jinhua W, Dongsheng L (2007) Optimization of solid-state medium for the production of inulinase by Kluyveromyces $\mathrm{S} 120$ using response surface methodology. Biochem Eng J 34:179-184

40. Gill PK, Manhas RK, Singh P (2006) Purification and properties of a heat-stable exoinulinase isoform from Aspergillus fumigatus. Bioresour Technol 97:894-902

41. Frisvad JC, Hubka V, Ezekiel CN, Hong SB, Novakova A, Chen AJ, Arzanlou M, Larsen TO, Sklenar F, Mahakarnchanakul W, Samson RA, Houbraken J (2019) Taxonomy of Aspergillus section flavi and their production of aflatoxins, ochratoxins and other mycotoxins. Stud Mycol 93:1-63

42. Singh. RS, Chauhan K, Singh. J, Pandey. A, Larroche (2018) C, Solid-State Fermentation of Carrot Pomace for the Production of Inulinase by Penicillium oxalicum BGPUP-4, Food Technol. Biotechnol 56:31-39

43. Singh RS, Dhaliwal. R, Puri. M (2006) Production of inulinase from Kluyveromyces marxianus YS-1 using root extract of Asparagus racemosus. Process Biochem 41:1703-1707

44. Phisit S, Hanmoungjai KA. P, Techapun. C, Chaiyaso. (2012) T, Leksawasdi. N, Optimization of exopolysaccharide overproduction by lactobacillus confusus in solid state fermentation under high salinity stress. Biosci Biotechnol Biochem 76:912-917

\section{Figures}




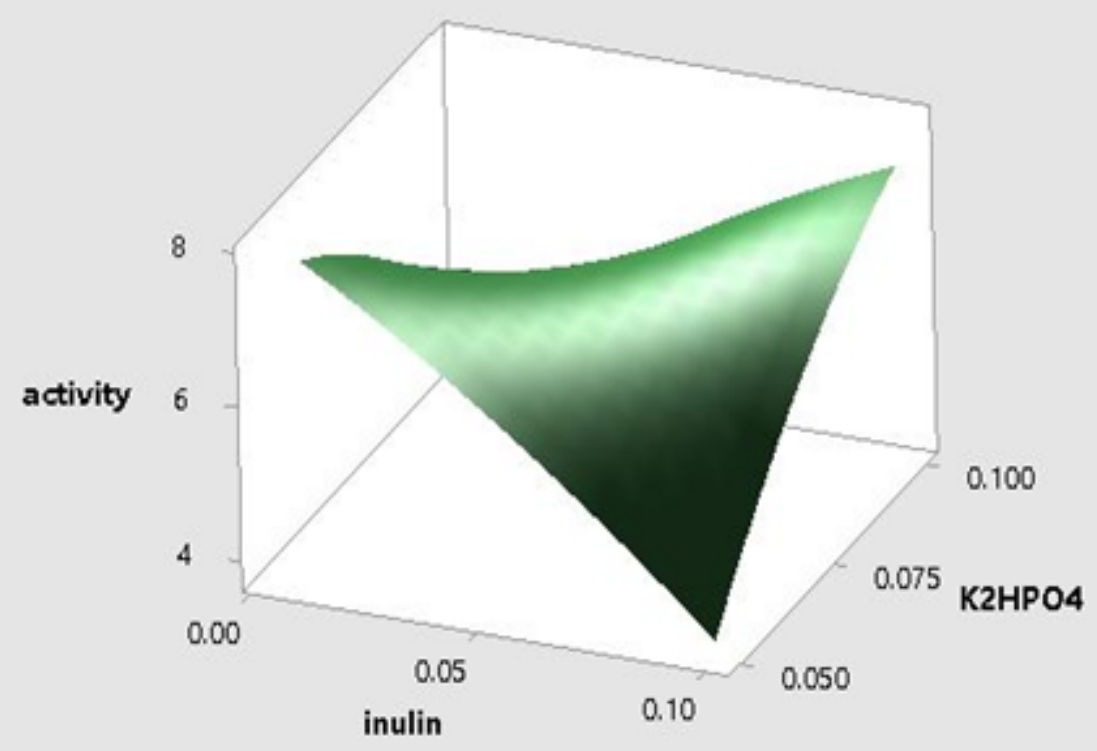

Figure 1

3D surface plot showing the effect of Inulin and K2HPO4 on the activity of inulinase enzyme.

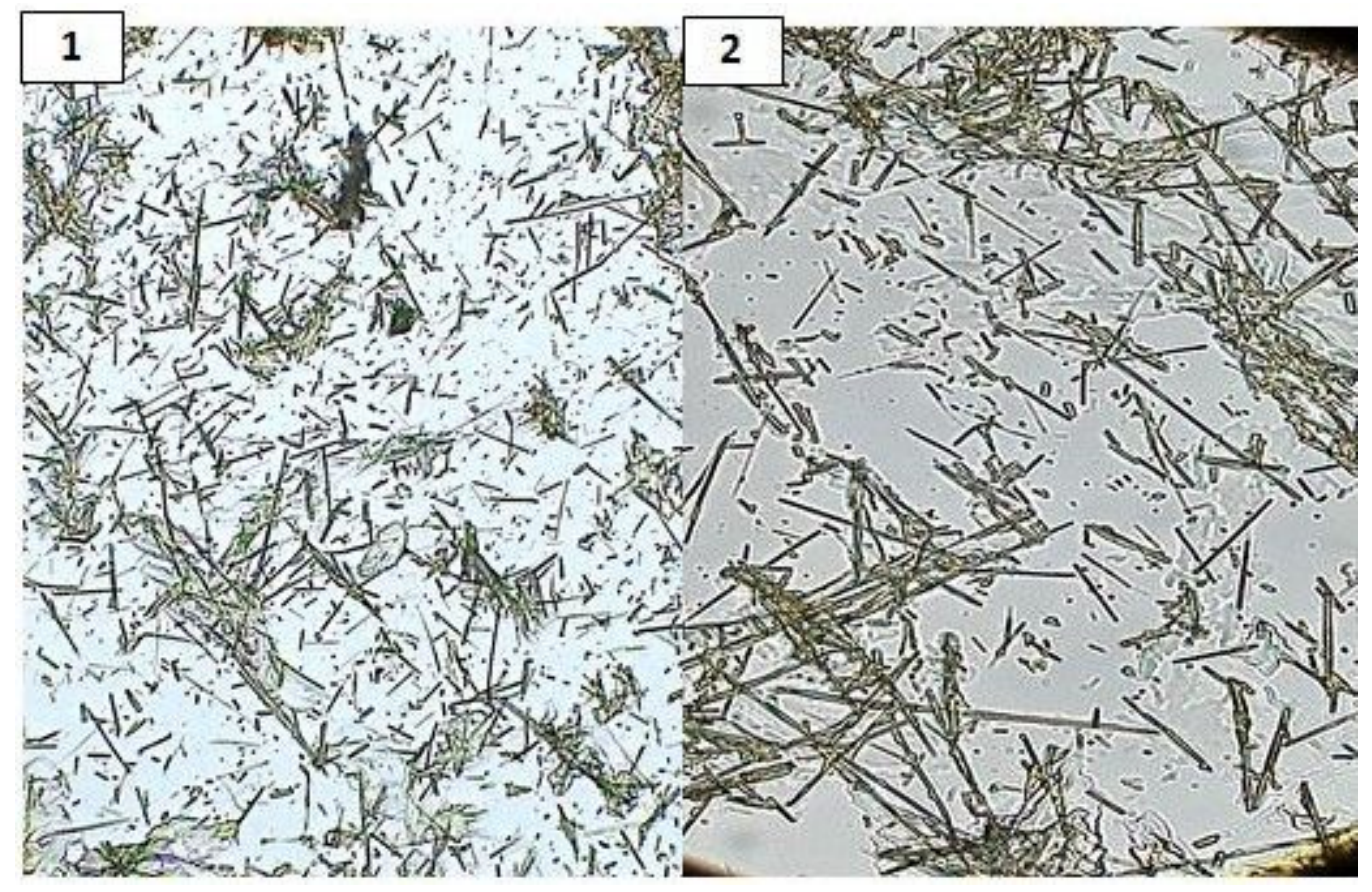

Figure 2 


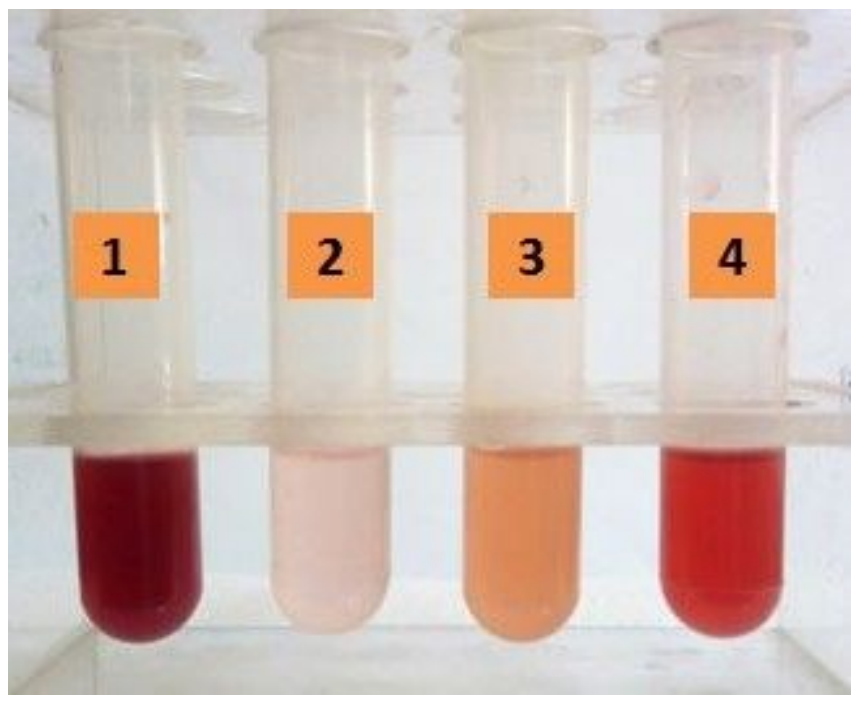

Figure 3

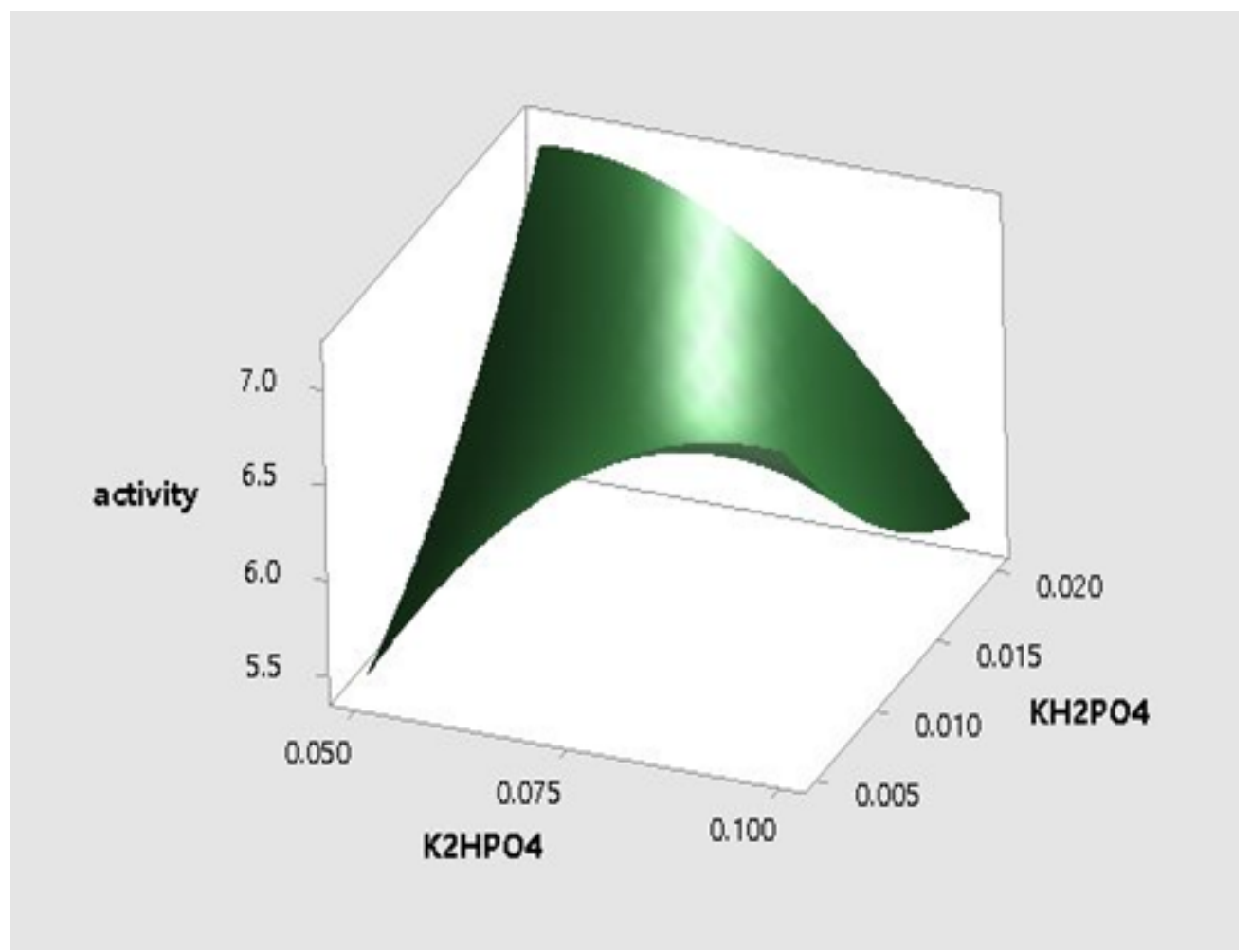

\section{Figure 4}

$3 \mathrm{D}$ surface plot showing the effect of $\mathrm{K} 2 \mathrm{HPO} 4 \mathrm{and} \mathrm{KH} 2 \mathrm{PO} 4$ on the activity of inulinase enzyme. 



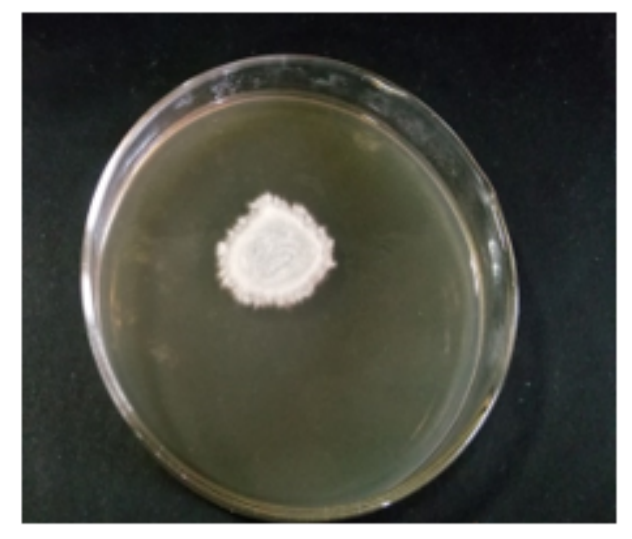

Fig. 1a- Growth of DD MSF 1 on inulin media

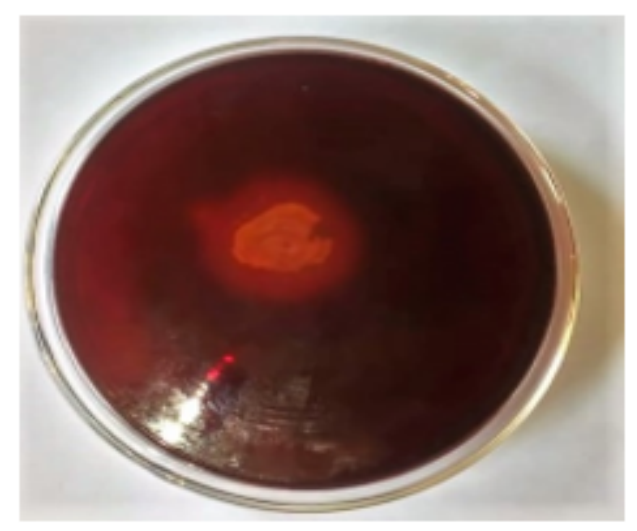

Fig. 1b- Formation of clear halo around DD MSF 1 after flooding with Luggl's iodine

\section{Figure 6}

1a- Growth of DD MSF 1 on inulin media. 1b- Formation of clear halo around DD MSF 1 after flooding with Lugol's iodine. 


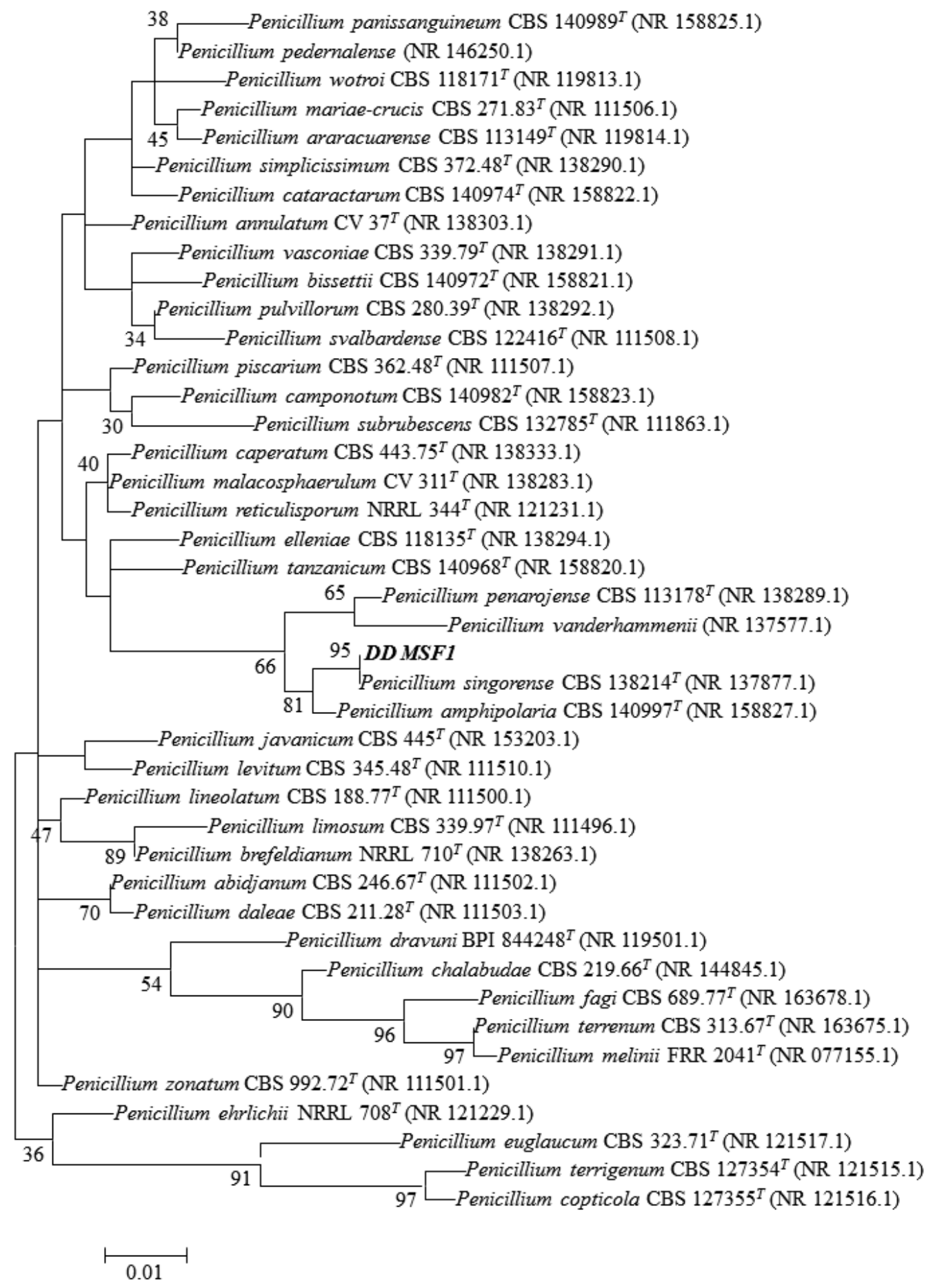

\section{Figure 7}

Phylogenetic tree of 18 s rRNA of the isolate Penicillium amphipolaria strain KAS 2555 shown as DD MSF 1.

\section{Supplementary Files}


This is a list of supplementary files associated with this preprint. Click to download.

- GraphicalAbstract.docx 